\title{
Information Reliability, Organizational Bank Structure, Interbank Competition and Relationship Lending Benefits
}

\author{
Loukil $\mathbf{S}^{*}$ and Jarboui AK
}

Department of Accounting and Finance, University of Sfax, Tunisia

\begin{abstract}
In this paper we study how does bank-borrower relationships benefits differ depending on three factors identified in the theoretical literature: verifiability of information, bank's organizational structure and interbank competition. We employ an empirical model that simultaneously accounts for all three of these factors to analyse how relationship lending affects credit cost. Our key result is that that borrowers with long relationship length are likely to be captured and deprived of larger rents and that the diversification of banking products moderate the hold-up problem. These latter findings suggest the possibility that relationship borrowers may suffer from capture effects. Moreover, we find evidence that close relationships benefit on credit cost is larger in a more competitive loan market. So, banks consider relationships as a device for product differentiation.
\end{abstract}

Keywords: Banks; Small business; Bank-borrower relationships; Loan interest rate

\section{Introduction}

Asymmetric information and effects on SMEs financing conditions is a research theme that has continued to see more and more interest. Indeed, firms with positive net present value investment opportunities may be deprived of investment because of adverse selection and moral hazard problem [1]. Among suggested solutions by theoretical and empirical literature, we distinguish the technology of relationship lending. Indeed, this type of financing depends on the accumulation of "soft" information over time by the banker. Despite relationship lending has been the subject of considerable recent research interest, the process of relationship lending is not well understood [2]. Understanding relational funding technology requires understanding the likely effect of certain factors. In fact, since the credit officer is responsible for producing this specific information, the agency problems created by the banking organization [2-5], the degree of banking competition [69] and the reliability of the information disclosed [10] could influence the benefits of a close banking relationship with the company. The contribution our study consists in studying simultaneously the effect of these three main factors in a dynamic perspective on the magnitude of the advantages of relational financing in terms of credit costs. The remainder of the paper is composed as follows. In section 4, we analyze the literature review and present the hypothesis concerning the potential effect of informational reliability, the organizational structure and the banking competition on relationship lending benefits. In section 5, we introduce our empirical methodology. We present our main results in section 6 and the final section concludes.

\section{Literature Review: Hypothesis}

\section{Informational reliability and relationship lending benefits}

Informational asymmetry is a central concept in the theory of financial intermediation developed by Diamond [11]. Indeed, Boot [12] states that the purpose of the bank is to mitigate the problems due to asymmetric information. Thus, information reliability plays a critical role in determining the efficiency of relational finance technology. The literature review shows that there are several financing technologies used by commercial banks to finance SMEs, namely transactional finance technologies and relational finance technology [13-16].
According to the current paradigm of relational financing, companies, having difficulty in transmitting information and are consequently constrained to finance on unfavourable conditions by banks with no access to public financial markets, benefit more from the establishment of a close financial relationship with their banks.

Boot [12] defines relationship banking as the provision of financial services by financial intermediary that invests in obtaining customerspecific information, often proprietary in nature and evaluates the profitability of these investments through multiple interactions with the same customer over time and/or across products. The relational finance technology is a technology based on "soft" information produced by the banker through direct and repetitive contacts with the manager of the company. Since this information is difficult to quantify and transmit, relational finance seems ideal for SMEs characterized by a certain degree of informational opacity. Indeed, developing a close banking relationship between the bank and the company appears to be the only way to accumulate "soft" information whereas transactional finance technologies do not depend on close financial relationships. Rather, these technologies depend on "hard" information, that is, financial statements certified by a statutory auditor [10]. In this context, Taketa and Udell [14] classified financing technologies by type of information required "hard" or "soft" (Table 1).

In the same way of Jianglini et al. [17] and Kano et al. [10], we will examine whether the effect of reducing the cost of credit by establishing a close financial relationship with the company varies depending on the quality of the information received. This leads us to test the following hypothesis:

H1: Reducing cost of credit through close banking relationship is more important for companies with no "hard" information.

*Corresponding author: Sahar Loukil, Department of Accounting and Finance University of Sfax, Tunisia, Tel: +21674242951; E-mail: saharloukil@windowslive.com

Received June 13, 2017; Accepted June 27, 2017; Published July 07, 2017

Citation: Loukil S, Jarboui AK (2017) Information Reliability, Organizational Bank Structure, Interbank Competition and Relationship Lending Benefits. J Bus Fin Aff 6: 275. doi: 10.4172/2167-0234.1000275

Copyright: ( 2017 Loukil S, et al. This is an open-access article distributed under the terms of the Creative Commons Attribution License, which permits unrestricted use, distribution, and reproduction in any medium, provided the original author and source are credited. 


\begin{tabular}{|c|c|c|c|}
\hline Technology & Type & Borrower & Information \\
\hline Relationship Lending & Relational & Opaque & Soft \\
\hline $\begin{array}{l}\text { Financial Statement } \\
\text { Lending }\end{array}$ & Transactional & Transparent & Hard \\
\hline Asset-Based Lending & Transactional & Opaque & Hard \\
\hline Factoring & Transactional & Opaque & Hard \\
\hline Leasing & Transactional & $\begin{array}{l}\text { Opaque and } \\
\text { transparent }\end{array}$ & Hard \\
\hline Small Bus. Credit Scoring & Transactional & Opaque & Hard \\
\hline Equipment Lending & Transactional & $\begin{array}{l}\text { Opaque and } \\
\text { transparent }\end{array}$ & Hard \\
\hline Real estate based lending & Transactional & $\begin{array}{l}\text { Opaque and } \\
\text { transparent }\end{array}$ & Hard \\
\hline Trade Credit & Transactional & $\begin{array}{l}\text { Opaque and } \\
\text { transparent }\end{array}$ & Soft and hard \\
\hline
\end{tabular}

Source: Taketa and Udell (2007).

Table 1: Lending technologies.

\section{Organizational structure of the bank and relationship lending benefits}

Several recent empirical studies have stressed that the organizational structure of the bank has a significant impact on the magnitude of the benefits of relational funding. This effect is explained by the fact that the bank's motivation in the production of "soft" information depends on its organizational structure [18]. According to Berger and Udell [2], considerable efforts have been made to analyse the impact of close relationship on SMEs financing but researchers have been interested in placing relational funding in the context of bank's organizational structure. The reasoning of Berger and Udell [2] is based on the idea that relational finance depends on the accumulation of "soft" information and that the banker is solely responsible for the accumulation and transmission of this kind of information. In this case, agency problems associated to information transmission can be resolved through a less complex organizational structure as though, small size, concentrated ownership structure with a reduced number of officers. Berger et al. [4] empirically find that small banks collect more "soft" information than large banks. The latter refrain from financing opaque firms. More specifically, the researchers studied the effect of the organizational structure through the following aspects:

- The size of the bank $[4,5]$.

- The financial system [9].

- The geographical distance between the bank and the company [7].

- Economic conditions [2].

- The switching costs [7].

According to the relationship lending theory, the size of the bank has a negative impact on the probability of getting a relational loan [2]. This finding stems from the prediction of Stein [18] which assumes that small banks have comparative advantages in producing "soft" information and large banks have more comparative advantages in lending based on "hard" information. Indeed, several empirical studies have found that large banks are less dedicated to financing SMEs. But in the case of bank mergers and acquisitions, banks tend to retain existing banking relationships with new entrants. Kano et al. [10] measured the effect of the bank type by adopting the current classification in the country of the study. Thereby, we will classify the banks according to the ownership structure, that is, in private or public. As a result, we will test the following hypothesis:

$\mathrm{H} 2$ : The reduction of the cost of credit, thanks to the establishment of a close banking relationship, is all the more important for companies that are moving towards a private bank.

\section{Interbank competition and benefits of relational funding}

Petersen and Rajan [3] are the first to examine the effect of interbank competition on the value of relational financing. They were able to empirically validate their hypothesis that lenders in a concentrated credit market, reassured to be able to extract future annuities, agree to finance companies in financial difficulty. Thus, relational financing is more developed in concentrated credit markets. Later and in the same logic, Boot and Thakor [6], through their article entitled "Can relationship survive competition?" have tried to know how will banks evolves as competition increases from other banks and from the capital market? Will banks become more like capital market underwriters and offer passive transaction loans or return to their roots as relationship lending experts? They found that as interbank competition increases, banks will move towards relational lending, but the marginal added value for lenders is decreasing.

By proposing an empirical review of works on the effect of interbank competition and the organizational structure of the banking system on relationship lending benefits, Degryse and Ongena $[7,8]$ found that the more the banking markets are concentrated, the greater the spread between the deposit and credit market, while increasing competition could reduce interest rates and also stimulate banks to establish close relationships with companies through the granting of several financial products. This type of relationship protects the rents of banks and offers an explanation of the increase in bankers' fees. Empirical works [19$21,9]$ show a non-monotonic relationship between the narrow banking relationship and the degree of interbank competition. Indeed, trying to know how banks respond to increased competition, Degryse and Ongena [9] found that when bank branches face stiff local competition, they engage much more in relational lending. Their results show that competition and close banking relationships are not necessarily hostile. Presbitero and Zazzaro [22] explain this non-monotonic relationship by the structure of the local credit market. They found that a marginal increase in interbank competition is crucial for relational financing in markets characterized by the presence of large banks and foreign banks. On the contrary, in the credit markets where relational financing is already developed through the existence of groups of small banks, an increase in competition encourages the latter to further cultivate their customer relationships. In conclusion, the net effect of interbank competition on the advantages of relational financing is a priori undetermined from a theoretical point of view, whereas the results of the empirical studies show a non-monotonic relationship. To determine the nature of this effect in the Tunisian context, we will test the following hypothesis:

H3: The reduction in the cost of credit, thanks to the establishment of a close banking relationship, is all the more important in a competitive banking market.

\section{Empirical Methodology}

We analyse data on credit lines considered by nature as relational credit since they require a daily monitoring by the banker of the state of commitments of the firm through direct and repetitive contact with the manager. This close relationship allows the banker to produce "soft" information that can enrich his database when making decisions to renew credit to SMEs. The latter are characterized by a higher level of informational asymmetry than those of larger size [23,11]. Our sample consisted of data on management credit files granted to 161 
SMEs during 2009-2011. Since we analyse the effect of informational reliability, the organizational structure of the bank and banking competition on relationship lending benefits, we will assume that the older firms are less opaque than the younger ones since the former have a longer history and are better known in the market than those newly created [24]. In the following, we will present the dependent and independent variables and specify the model to be estimated.

\section{Variables}

According to the current relational finance paradigm, a close financial relationship between the bank and the company improves the financing conditions thanks to the banker's ability to produce "soft" information. Drawing on the methodology [10], we will analyze the extent of this impact through the following three factors: information reliability, banking competition and the bank's organizational structure. We measure the cost of credit through the variable RATE corresponding to the bank's profit margin relative to its refinancing rate. Our key explanatory variables are two relationship variables. The first variable DURATION represents the length of the relationship between the SME and the bank based on a survey question that asks how many years the firm has had a business relationship with its current main bank since the company first opens a current account. The "simple" theory of relationship lending suggests that duration will have a negative effect on credit cost. But, we further focus on the magnitude effect due to the three factors described above. Note, however, that, a positive impact of DURATION on credit cost may also be a theoretical possibility when the borrower is captured by the bank because longer relationships makes it difficult to replace the lending bank and thus the borrower is locked into the relationship [25-28].

Second, we use a proxy variable to capture the effect of the banking relationship scope $[29,30,5]$. Like duration, the relationship scope is intended to reflect the strength of the banking relationship and the ability of the relationship bank to acquire soft information. The variable SCOPE indicates the scope of the banking relationship, measured by the natural logarithm of the number of lines of credit granted to the company. However, there are two theoretical possibilities for the impact of the scope as it is the case for the banking relationship duration. As explained in the previous section, we want to take into account the difference in the association between relationship variables and the three factors: information verifiability, the bank's organizational structure and competition in the banking market. First, information verifiability is approximated by a dummy variable representing the availability of audited financial documents. Our survey asks if SMEs have financial statements and if they were certified. A dummy variable, NO-AUDIT, takes a value of one if the SME's financial statements are not audited by certified public accountants. Hypothesis 1 implies that the relationship variables should have a significant and negative effect on the dependent variable for the firms with NO_AUDIT=1. Second, to proxy for organizational size and complexity, we use dummy for bank ownership structure. The empirical review identifies several aspects of the bank's organizational structure, such as size, age, ownership structure and organizational complexity 1 . In Japan banking markets are segmented by bank type [10]. While in the case of Tunisian banking markets, we can differentiate between banks through the ownership structure. Because these bank types are quite distinct in terms of ownership, we can test Stein's [18] theory of bank organization and relationship lending using proxies for bank types. Thus, the ownership of banks is approximated by the dummy variable PUB indicating whenever the bank is public and not private. Petersen and Rajan [3] have shown that inter-bank competition is important in determining the benefits of relational financing. But, the theoretical predictions about the likely effect of competition on SME financing conditions are inconclusive. Degryse and Ongena $[7,8]$ identify interbank competition through the number of branches (or alternatively the concentration of the branch) and the distance between the borrower and the competitive banking branches in the vicinity of the firm. Petersen and Rajan [3] postulate that "if the Herfindahl index for deposits is a good proxy for competition in the loan market, we would expect to find more solicitation of new business by financial institutions in more competitive markets". Our main measure of competition is the Herfindahl-Hirschman Index (HHI). This variable is a measure of concentration in the literature and is widely used as a measure of competition in empirical works $[3,6,21]$. We define HHI as the summed squares of bank market shares and analyze it's evolution over time during 2009-2011. Finally, as control variables, we include variables to represent: firm-specific characteristics and industry dummies. These variables control for, among other things, firm risk, industry risk and the differences in the average loan characteristics at the bank level. We include firm size, ownership, legal form and industry. Younger, smaller, more profitable and highly leveraged firms are often hypothesized to seek more intense bank relationships. Younger and smaller firms are often opaque, lack a track record of hard financial information, or do not have assets that can serve as collateral. Relationship finance is the best lending technology available to service such firms [13]. More profitable, high quality firms may seek confidentiality in a bilateral relationship financing, to minimize the loss of proprietary firm information [31], while highly leveraged firms may prefer to renegotiate with a single relationship lender in times of distress (Table 2).

\section{Model specification}

In order to test empirically the assumptions already made $(1,2$ and 3) and to understand how the reliability of the information, the organizational structure of the bank and the interbank competition affect the advantages of relational financing in terms of the cost of credit, we will integrate in our model the terms of interaction between measures of the narrow banking relationship and the three factors already cited. We propose the following model:

Cost of credit=f (relational intensity, informational reliability, organizational structure of the bank, interbank competition, control variables) (Table 3).

The global regression model including all interaction variables is as follows:

$\operatorname{RATE}_{\mathrm{i}, \mathrm{t}}=a_{\mathrm{DPi}, \mathrm{t}}$ DURATION * PUB ${ }_{\mathrm{i}, \mathrm{t}}+\alpha_{\mathrm{DC}, \mathrm{t}}$ DURATION * $\mathrm{HHI}_{\mathrm{i}, \mathrm{t}}+\alpha_{\mathrm{DNi,t}}$ DURATION $*$ NO-AUDIT $i, t+\beta_{\mathrm{SP}, \mathrm{t}}$ SCOPE $_{\mathrm{i}, \mathrm{t}} * \mathrm{PUB}_{\mathrm{i}, \mathrm{t}+\mathrm{SCi}, \mathrm{t}} \beta_{\mathrm{SC}}$ $\operatorname{SCOPE}_{\mathrm{i}, \mathrm{t}} \stackrel{\mathrm{DNi,t}}{*} \mathrm{HHI}_{\mathrm{i}, \mathrm{t}}+\beta_{\mathrm{SNi}, \mathrm{t}} \mathrm{SCOPE}_{\mathrm{i}, \mathrm{t}} * \mathrm{NO}-\mathrm{AUDIT}_{\mathrm{i}, \mathrm{t}}+\lambda_{\mathrm{Ait}, \mathrm{t}} \mathrm{AGE}+\lambda_{\mathrm{Ai}, \mathrm{t}}$

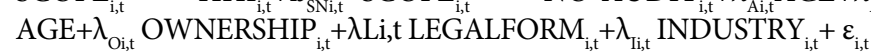

With $\mathrm{i}=1 \rightarrow 161$ et $\mathrm{t}=1 \rightarrow 3$

\section{Results}

\section{Methodological aspects}

In this section, we will estimate the effect of asymmetric information, organizational structure and banking competition on the relationship lending benefits, the credit cost, through the introduction of six interactions terms between these three factors and the two relationship proxies namely the scope and the duration of the relationship. However, before estimating the different regression models, it is essential to test the absence of correlation between the explanatory variables. 


\begin{tabular}{|c|c|c|c|c|c|c|}
\hline Variables & Indication & Measure & Mean & Std. Dev. & Min. & Max. \\
\hline Credit cost & RATE & $\begin{array}{l}\text { The margin of the bank compared to its } \\
\text { refinancing rate }\end{array}$ & 0.029479 & 0.010133 & 0.0125 & 0.045 \\
\hline Relationship duration & DURATION & $\begin{array}{l}\text { The natural logarithm of the number of years since } \\
\text { the opening of a current account with the bank. }\end{array}$ & 10.67081 & 8.317938 & 1 & 35 \\
\hline Relationship scope & SCOPE & $\begin{array}{l}\text { The natural logarithm of the number of credit } \\
\text { lines held at the bank. }\end{array}$ & 3.225673 & 1.432001 & 0 & 8 \\
\hline Interbank competition & $\mathrm{HHI}$ & $\begin{array}{l}\text { Hirschmann Herfindahl index measured by the } \\
\text { sum of the squares of the market shares of the } \\
\text { banks in terms of credit granted to customers }\end{array}$ & 0.095667 & 0.002497 & 0.093 & 0.099 \\
\hline Firm size & SIZE & The natural logarithm of the annual turnover. & 3100.745 & 3759111 & 45 & 25367000 \\
\hline Firm age & AGE & $\begin{array}{l}\text { The natural logarithm of age measured in } \\
\text { number of years. }\end{array}$ & 14.2795 & 1.070534 & 1 & 60 \\
\hline \multicolumn{2}{|c|}{ Binary variables } & Measure & \multicolumn{2}{|c|}{ Frequency } & \multicolumn{2}{|c|}{ Percentage } \\
\hline \multirow[t]{2}{*}{ Legal form of the company } & \multirow[t]{2}{*}{ LEGALFORM } & & \multicolumn{2}{|c|}{385} & \multicolumn{2}{|c|}{0.8} \\
\hline & & $=1$ if the firm is a limited liability company & \multicolumn{2}{|c|}{95} & \multicolumn{2}{|c|}{0.2} \\
\hline \multirow[t]{2}{*}{ Ownership of the firm } & \multirow[t]{2}{*}{ OWNERSHIP } & $=0$ otherwise. & \multicolumn{2}{|c|}{381} & \multicolumn{2}{|c|}{0.79} \\
\hline & & $=1$ if the manager holds at least $50 \%$ of & \multicolumn{2}{|c|}{102} & \multicolumn{2}{|c|}{0.21} \\
\hline \multirow[t]{2}{*}{ Informational asymmetry } & \multirow[t]{2}{*}{ NO-AUDIT } & $=0$ otherwise. & \multicolumn{2}{|c|}{228} & \multicolumn{2}{|c|}{0.48} \\
\hline & & $\begin{array}{c}=1 \text { if the financial statements are not } \\
\text { Certified. }\end{array}$ & \multicolumn{2}{|c|}{255} & \multicolumn{2}{|c|}{0.53} \\
\hline \multirow[t]{2}{*}{ Bank organizational structure } & \multirow[t]{2}{*}{ PUB } & $=0$ otherwise & \multicolumn{2}{|c|}{150} & \multicolumn{2}{|c|}{0.32} \\
\hline & & $=1$ if the bank is public & \multicolumn{2}{|c|}{333} & \multicolumn{2}{|c|}{0.68} \\
\hline \multirow[t]{2}{*}{ Industry of the firm } & \multirow[t]{2}{*}{ INDUSTRY } & \multirow[t]{2}{*}{$=0$ if it is private } & \multicolumn{2}{|c|}{237} & \multicolumn{2}{|c|}{0.49} \\
\hline & & & \multicolumn{2}{|c|}{246} & \multicolumn{2}{|c|}{0.51} \\
\hline \multicolumn{2}{|c|}{ Number of observation } & \multicolumn{5}{|c|}{483} \\
\hline
\end{tabular}

Table 2: Variable names, indication variable definition sand sample statistics.

\begin{tabular}{|c|c|c|}
\hline Hypothesis to be tested & Interaction variables & Coefficient \\
\hline \multirow{2}{*}{$\begin{array}{l}\text { Effect of informational asymmetry on } \\
\text { the advantages of relational financing }\end{array}$} & DURATION*NO-AUDIT & $\alpha \mathrm{DN}$ \\
\hline & SCOPE*NO-AUDIT & BSN \\
\hline \multirow{2}{*}{$\begin{array}{l}\text { Effect of the organizational structure } \\
\text { on the benefits of relational funding }\end{array}$} & DURATION*PUB & $\alpha \mathrm{DP}$ \\
\hline & SCOPE*PUB & B SP \\
\hline \multirow{2}{*}{$\begin{array}{l}\text { Effect of interbank competition on the } \\
\text { advantages of relational financing. }\end{array}$} & DURATION* HHI & $\alpha \mathrm{DC}$ \\
\hline & $\mathrm{SCOPE}{ }^{*} \mathrm{HHI}$ & BSC \\
\hline
\end{tabular}

Table 3: Hypothesis testing

We calculated the Pearson correlation coefficients between these variables as well as the VIF "Variance Inflation Factor" which measures how much the variance of an estimated regression coefficient is increased because of co-linearity and the index of tolerance of variables measured by the expression (1-R2j) of the regression of each variable on the (P-1) other independent variables. The closer this value is to zero, the more there is a problem of multi-collinearity. Examination of the correlation matrix shows that all correlation coefficients are less than 0.8. According to Kennedy, there is no serious problem of multicollinearity. Moreover, we can note that all our explanatory variables have a value of the Variable Inflation Factor (VIF) less than 10, the limit recommended by Chatterjee et al. [32] (Table 4).

\section{Empirical results}

The results of the econometric regression of the dependent variables measuring credit cost on the set of asymmetric information, organizational structure and banking competition and control variables through the GLS regression based on panel data are presented in the next table (Table 5).

The first step in the implementation of linear regression is to determine the relevance of the global model. The aim is to specify the representation quality of the model and the global significance of the coefficients associated to the explanatory variables 4 . The Wald $\chi^{2}$ test of the overall significance of the regression thus represented in Table 5 is significant at the $1 \%$ level $\left(\operatorname{Prob}>\chi^{2}=0.000\right)$. Thus, the explanatory power of the model is satisfactory. The evaluation of the linear adjustment quality of the regression equation between the dependent variable and the independent variables is determined by the coefficient of determination $\mathrm{R}^{2}$. It represents the percentage of the explained variance of the dependent variable by the model. The proportion that remains unexplained $\left(1-\mathrm{R}^{2}\right)$ is due either to the omission of explanatory variables that could contribute to the explanation of the cost of credit or to experimental error. According to the table, the coefficient of determination is equal to $35.55 \%$. In other words, $35.55 \%$ of the variation in the cost of credit is explained by the combinations of measures of relational intensity with the three factors taken into account: banking competition, the organizational structure of the bank and the information reliability of the company as well as the control variables.

Bank-borrower relationships and information verifiability: The results of the estimation of our model show that the cost of credit increases for companies whose financial statements are not certified even if it maintains close banking relationships through long relationship duration. This is evident through the positive coefficient $\alpha \mathrm{DN}=0.0034185$ of the variable DUR ${ }^{*} \mathrm{NO}$-AUDIT which is significant at the $1 \%$ threshold. So, we cannot validate the first hypothesis. On the other hand, we found that the relationship scope, approximated by the number of management credit lines obtained, allows informally unreliable firms to get credit line at lower cost. Indeed, the variable $\mathrm{SCOPE}_{\mathrm{i}, \mathrm{t}} * \mathrm{NO}^{\mathrm{N}} \mathrm{AUDIT}_{\mathrm{i}, \mathrm{t}}$ has a significantly negative coefficient $\beta S N=-.0022963$ at the threshold of $10 \%$. So we can validate the first hypothesis when we consider relationship strength through the scope and not duration. This is not the case for Kano et al. [10]. They found that relationship scope for unaudited firms is associated with a higher interest rate. This result could be explained by the difference in measurement used since these researchers measured the relationship scope by the first component of five binary variables indicating the existence of a type of banking service. So, reducing the cost of credit for companies that do not have certified financial statements is arbitrary 
Citation: Loukil S, Jarboui AK (2017) Information Reliability, Organizational Bank Structure, Interbank Competition and Relationship Lending Benefits. J Bus Fin Aff 6: 275. doi: 10.4172/2167-0234.1000275

Page 5 of 7

\begin{tabular}{|c|c|c|c|c|c|c|c|c|c|c|c|c|c|c|}
\hline & RATE & $\begin{array}{l}\text { DUR* } \\
\text { NOAUDIT }\end{array}$ & $\begin{array}{l}\text { DUR* } \\
\text { PUB }\end{array}$ & DUR $^{*}$ HHI & $\begin{array}{l}\text { SCOPE* }^{*} \\
\text { NOAUDIT }\end{array}$ & $\begin{array}{l}\text { SCOPE* } \\
\text { PUB }\end{array}$ & $\begin{array}{l}\text { SCOE* }^{*} \\
\text { HHI }\end{array}$ & AGE & SIZE & OWNER & $\begin{array}{l}\text { LEGAL } \\
\text { FORM }\end{array}$ & INDUSTRY & VIF & $1 / \mathrm{VIF}$ \\
\hline RATE & 1 & & & & & & & & & & & & & \\
\hline DUR*NOAUDIT & $0.2829^{*}$ & 1 & & & & & & & & & & & 5.32 & 0.18813 \\
\hline DUR*PUB & $0.2916^{*}$ & $0.2207^{*}$ & 1 & & & & & & & & & & 5.31 & 0.188457 \\
\hline DUR*HHI & $-0.3464^{*}$ & $0.2410^{*}$ & $-0.1004^{*}$ & 1 & & & & & & & & & 3.74 & 0.26744 \\
\hline SCOPE*NOAUDIT & $0.2122^{*}$ & $0.7960^{*}$ & $0.1415^{\star}$ & 0.0137 & 1 & & & & & & & & 3.71 & 0.269337 \\
\hline SCOPE*PUB & $0.2687^{*}$ & 0.0634 & $0.7404^{*}$ & $-0.3604^{*}$ & $0.2395^{*}$ & 1 & & & & & & & 3.26 & 0.306619 \\
\hline SCOPE*HHI & $-0.3856^{*}$ & -0.0049 & $-0.1922^{*}$ & $0.2884^{*}$ & $0.2709^{*}$ & 0.0304 & 1 & & & & & & 2.6 & 0.384523 \\
\hline AGE & $-0.3590^{*}$ & 0.0682 & $-0.2034^{*}$ & $0.7455^{\star}$ & $-0.1099^{*}$ & $-0.3485^{*}$ & $0.2735^{*}$ & 1 & & & & & 1.87 & 0.534511 \\
\hline OWNERSHIP & $-0.2834^{\star}$ & -0.0341 & $-0.4199^{*}$ & $0.2041^{*}$ & -0.0109 & $-0.3354^{*}$ & $0.1338^{*}$ & $0.0957^{*}$ & $-0.1462^{*}$ & 1 & & & 1.19 & 0.838482 \\
\hline LEGALFORM & $0.2066^{*}$ & $0.1739^{*}$ & $0.1398^{\star}$ & $-0.1314^{*}$ & $0.1373^{*}$ & $0.1520^{*}$ & $-0.1710^{*}$ & $-0.2302^{*}$ & 0.0374 & -0.0646 & 1 & & 1.1 & 0.905763 \\
\hline INDUSTRY & 0.0531 & $-0.0992^{*}$ & -0.0323 & -0.0109 & -0.0171 & 0.0189 & 0.0875 & 0.0151 & -0.0749 & -0.0662 & $-0.2499^{\star}$ & 1 & 1.1 & 0.908957 \\
\hline
\end{tabular}

*Significant at $10 \%$ level. ${ }^{* *}$ Significant at $5 \%$ level. ${ }^{* *}$ Significant at $1 \%$ level.

Table 4: Correlation table.

\begin{tabular}{|c|c|c|c|c|c|c|}
\hline \multicolumn{7}{|c|}{ Cross-sectional time-series GLS regression with random effect } \\
\hline \multicolumn{7}{|c|}{ Coefficients: Generalized Least Squares Panels: Heteroskedastic with cross-sectional correlation } \\
\hline \multicolumn{3}{|c|}{ Number of observations $=\mathbf{4 8 3}$} & \multicolumn{4}{|c|}{$\begin{array}{c}\text { Number of groups }=161 \\
\text { Time periods }=3\end{array}$} \\
\hline Rate & Coef. & Std. Err. & Z & $\mathrm{P}>|\mathrm{z}|$ & \multicolumn{2}{|c|}{ [95\% Conf. Interval] } \\
\hline DUR*NOAUDIT & $.0034185^{\star * *}$ & 0.000793 & 4.31 & 0 & 0.001865 & 0.004973 \\
\hline DUR*PUB & 0.000297 & 0.000872 & 0.34 & 0.733 & -0.00141 & 0.002006 \\
\hline DUR*HHI & $-.0251219^{* * *}$ & 0.0092 & -2.73 & 0.006 & -0.04315 & -0.00709 \\
\hline SCOPE*NOAUDIT & $-.0022963^{*}$ & 0.001383 & -1.66 & 0.097 & -0.00501 & 0.000415 \\
\hline SCOPE*PUB & 0.0005067 & 0.001443 & 0.35 & 0.725 & -0.00232 & 0.003335 \\
\hline SCOPE*HHI & $-.0161603^{* *}$ & 0.007923 & -2.04 & 0.041 & -0.03169 & -0.00063 \\
\hline Age & $-.0029249^{* * *}$ & 0.000888 & -3.29 & 0.001 & -0.00466 & -0.00118 \\
\hline Size & $-2.03 e-08$ & $1.97 e-08$ & -1.03 & 0.305 & $-5.89 e-08$ & $1.84 \mathrm{e}-08$ \\
\hline Ownership & $-.0042683^{* *}$ & 0.001697 & -2.51 & 0.012 & -0.00759 & -0.00094 \\
\hline Industry & $.0021608^{*}$ & 0.001209 & 1.79 & 0.074 & -0.00021 & 0.00453 \\
\hline Legalform & 0.001888 & 0.001508 & 1.25 & 0.21 & -0.00107 & 0.004843 \\
\hline Constant & $.0414592^{\star * *}$ & 0.002642 & 15.69 & 0 & 0.036281 & 0.0466377 \\
\hline Overall R-sq & \multicolumn{6}{|c|}{0.3555} \\
\hline $\begin{array}{l}\text { Wald }\left(\text { Prob> } x^{2}\right) \\
\quad(0.0000)\end{array}$ & \multicolumn{6}{|c|}{$119.33(0.0000)$} \\
\hline \multicolumn{7}{|c|}{ Breusch-Pagan Lagrangian Multiplier Test for Random Effects } \\
\hline$X^{2}$ Prob $>x^{2}$ & \multicolumn{6}{|c|}{$359.03(0.0000)$} \\
\hline
\end{tabular}

* Significant at $10 \%$ level. **Significant at $5 \%$ level. ${ }^{* * *}$ Significant at $1 \%$ level.

Table 5: Empirical results of the GLS regression with random effect

of the number of lines of credit and not of the duration of the banking relationship as a source of confidence for the banker. One possible interpretation for this inconsistency is again the capture effect, where these firms are too dependent on their main banks with respect to banking services, but they cannot find other lenders due to the lack of verifiable information (audited financial statements).

Bank-borrower relationships and bank organizational structure: The results of the estimation clearly show that the impact of the length and the scope of the banking relationship on the interest rate do not depend on the bank organizational structure approximated by the bank's ownership. In fact, the two variables DURPUB and SCOREPUB have successively positive and non-significant coefficients $\alpha \mathrm{DP}=0.000297$ and $\beta \mathrm{SP}=0.0005067$. On balance, we can conclude that in the case of our country, the effect of the narrow banking relationship measured in terms of duration and scope is independent of the type of bank. Therefore, we could not validate the second hypothesis. The results of Kano et al. [10] suggest, at least weakly, that with longer relationships with smaller banks, the loan interest rate decreases. They found that 10 years of an additional relationship with a small bank lowers the interest rate by $0.032 \%$ and $0.048 \%$ points when the bank is respectively a regional and a Shinkin bank. Their results imply that the capture effect is found when a lending bank is large and is absent for small banks. The positive impact of relationship length is inconsistent with the finding of Berger and Udell [33]. Angelini et al. [34] find that the length of the relationship has a positive impact on a loan interest rate when the lending bank is large, and that it has a negative (reducing) impact when the lending bank is small.

Bank-borrower relationships and bank competition: Concerning the impact of interbank competition, we found that the interest rate depends on the level of competition in the banking market. The analysis of the interaction terms allows us to conclude to the importance of the effect of a small variation in the level of competition, measured by the Herfindahl Hirschmann index. In Tunisia, the value of this index is less than 0.1 for the period between 2009 and 2011, the Tunisian market is considered to be not very concentrated. So there is an interbank competition. The analysis of the results of the econometric estimation shows that interbank competition reduces the cost of credit with negative coefficients $\alpha \mathrm{DC}=-0.0251219$ and $B S C=-0.0161603$ and significant at the threshold of 10 and $5 \%$. We have thus been able to validate the third hypothesis. This result is not only statistically 
significant but rather economically significant. Indeed, this observation validates the central hypothesis of the theory of relational financing concerning the positive effect of the narrow banking relationship in supporting informational opaque firms. In addition, our results are part of the studies carried out by Boot and Thakor [6] and Degryse and Ongena [7] arguing that when the market becomes competitive, banks opt for a close financial relationship as a source of competitive advantages to keep customers. On balance, this model finds that lenders with a soft information advantage tend to lend at lower cost.

Effect of business characteristics on the cost of credit: We find that, in addition to the impact of relationship strength, certain characteristics of the firm might encourage the banker to offer concessional credit line. Indeed, the estimated coefficient of the age of the firm is significantly negative $(\lambda \mathrm{A}=-0.0029249)$ at the $1 \%$ threshold. So, more the company is older the more likely it is to get competitive interest rates. Several researchers consider age to be one of the best proxy measures of the degree of informational asymmetry in the sense that the old company has a history reflecting its financial reality. Our finding of negative coefficients is not consistent with this theory. The theory is consistent with the positive coefficient on firm age in Table 5 to the extent that older firms have more publicly available information diminishing the informational advantage of relationship banks. This clearly contradicts the relationship lending hypothesis that predicts that banking relationships benefit younger borrowers. This inconsistency between the firm age and credit cost may be reconcilable. It seems to imply instead that older borrowers strong with their negotiation power could get lower credit rates. In addition, companies with at least $50 \%$ of the capital held by the manager are more likely to get favorable credit rate. Indeed, the ownership structure of the company has a negative coefficient $(\lambda \mathrm{P}=-0.0042683)$ and significant at the $5 \%$ threshold. This result could be explained by the fact that the more the manager maintains capital the more he is concerned by the good exploitation of the financial resources and this creates confidence links with the banker. Finally, we noted that bankers consider that business industry of the company is an important determinant when setting the profit margin of the bank. Indeed, the variable industry has a significant and positive coefficient $(\lambda \mathrm{I}=0.0021608)$ at the threshold of $10 \%$. Thus, banks set non-competitive interest rates on firms belonging to the industrial sector compared to those belonging to the service sector. Consistent with the overall results from the interest rate regression, these results on balance suggest that borrowers with long relationship length are likely to be captured and deprived of larger rents and that the diversification of banking products moderate the hold-up problem. The reducing effect of scope on the credit cost is also consistent with our findings. There is a piece of anecdotal evidence that could also reconcile the inconsistency in our results from a different angle. Firms may thus be willing to accept a high interest rate until they "graduate" from a lower-ladder bank to an upper level bank. A similar and related interpretation is that, if a strong relationship with a bank is formed as a risk-hedging mechanism, borrowers may be willing to incur a higher cost of borrowing under normal business conditions so as to provide incentives for banks to rescue them in bad times.

\section{Conclusion}

The review of the theoretical and empirical literature on relational financing allows us to conclude to the relevance of close banking relationship establishing. But, few researches have focused on the effect of informational reliability, the organizational structure of the bank and the degree of interbank competition on the magnitude of these benefits. To do this, we estimated the effect of the interaction terms including both these three factors and the proxy's measures of the relational intensity. The empirical results show that the reduction in the cost of credit for companies with no certified financial statements is arbitrary of the number of lines of credit and not the duration of the banking relationship as a source of confidence for the banker. Viewed from a relationship lending standpoint, it would therefore be interesting to examine why product diversification is an incentive to relationship lending advantages and not the relationship duration. As regards to the ownership structure of the bank, we found that the effect of banking relationship is independent from the bank ownership. According to the value of the Herfindahl Hirschmann index, our banking market is fairly competitive. The results show that the reduction in the interest rate through the relational intensity, measured by the duration and scope of the relationship, depends on the degree of market concentration and therefore on interbank competition. Thus, when the market is competitive, banks opt for the establishment of a banking relationship as a source of comparative advantage. Finally, in addition to the relational intensity, certain characteristics of the company might encourage the banker to offer credits at concessional terms. Indeed, the older the firm is, the more its capital is held by the manager, will the more likely get management credits at competitive interest rates, while it's not the case of those belonging to the industrial sector. We can conclude that the reducing effect of the relational intensity on the interest rate depends on the reliability of the information and the degree of interbank competition and not on the ownership structure of the bank.

\section{References}

1. Stiglitz JE, Weiss A (1981) Credit rationing in markets with imperfect information Am Econ Rev 71: 393-410.

2. Berger AN, Udell GF (2002) Small business credit availability and relationship lending: The importance of bank organizational structure. The Economic Journal 112: F32-F53.

3. Petersen M, Rajan R (1995) The benefits of lending relationships: Evidence from small business data. The Journal of Finance 49: 3-37.

4. Berger AN, Clarke G, Cull R, Klapper L, Udell G (2005) Corporate governance and bank performance: A joint analysis of the static, selection, and dynamic effects of domestic, foreign, and state ownership. Journal of Banking and Finance 29: 2179-2221.

5. Uchida H, Udell G, Watanabe W (2008) Bank size and lending relationships in Japan. Journal of the Japanese and International Economies 22: 242-267.

6. Boot $A$, Thakor $A(2000)$ Can relationship banking survive competition. Journal of Finance 55: 679-713.

7. Degryse H, Ongena S (2005a) Distance, Lending Relationships and Competition. The Journal of Finance.

8. Degryse $\mathrm{H}$, Ongena $\mathrm{S}(2005 \mathrm{~b})$ Competition and regulation in the banking sector: A review of the empirical evidence on the sources of bank rents.

9. Degryse H, Ongena $S$ (2007) The impact of competition on bank orientation Journal of Financial Intermediation 16: 399-424.

10. Kano M, Uchida H, Udell GF, Watanabe W (2010) Information verifiability, bank organization, bank competition and bank borrower relationships. Journal of Banking and Finance 35: 935-954.

11. Diamond D (1984) Financial intermediation and delegated monitoring. The Review of Economic Studies 51: 393-414.

12. Boot A (2000) Relationship banking: What do we know. Journal of Financial Intermediation 9: 7-25.

13. Berger AN, Udell GF (2006) A more complete conceptual framework for SME finance. Journal of Banking and Finance 30: 2945-2966.

14. Taketa K, Udell GF (2006) Lending channels and financial shocks: The case of SME trade credit and the Japanese banking crisis. Monetary and Economic Studies 25: 1-44. 
Citation: Loukil S, Jarboui AK (2017) Information Reliability, Organizational Bank Structure, Interbank Competition and Relationship Lending Benefits. J Bus Fin Aff 6: 275. doi: 10.4172/2167-0234.1000275

Page 7 of 7

15. Torre A, Peria M, Schmukler S (2010) Bank involvement with SMEs: beyond relationship lending. Journal of Banking and Finance 34: 2280-2293.

16. Berger AN, Black LK (2011) Bank size, lending technologies and small business finance. Journal of Banking and Finance 35: 724-735.

17. Jianglini $W$, Unal $H$, Yom $C$ (2008) lending, accounting disclosure, and credit availability during the Asian financial crisis. Journal of Money, credit and Banking 40: 25-55.

18. Stein JC (2002) Information production and capital allocation: Decentralized versus hierarchical firms. The Journal of Finance 57: 1891-1921.

19. Dinc S (2000) Bank Reputation, Bank Commitment, and the Effects of Competition in Credit Markets. Review of Financial Studies 13: 781-812.

20. Yafeh L, Yosha OY (2001) Industrial Organization of Financial Systems and Strategic Use of Relationship Banking. European Finance Review 5: 63-78.

21. Elsas R (2005) Empirical determinants of relationship lending. Journal of Financial Intermediation 14: 32-57.

22. Presbitero AF, Zazzaro A (2011) Competition and relationship lending: Friends or foes. Journal of Finance Intermediation, pp: 387-413.

23. Fama EF (1985) What's different about bank. Journal of Monetary Economics 15: 29-39.

24. Krishnaswami $P$, Spindt V, Subramaniam $P$ (1999) Information asymmetry, monitoring and the placement structure of corporate debt. Journal of Financial Economics 51: 407-434.

25. Greenbaum S, Kanatas, G, Venezia I (1989) Equilibrium loan pricing under the bank client relationship. Journal of Banking \& Finance 13: 221-235.
26. Sharpe S (1990) Asymmetric information, bank lending, and implicit contracts A stylized model of customer relationships. The Journal of Finance 45: 10691087.

27. Rajan RG (1992) Insiders and Outsiders: The Choice between Informed and Arm's-Length Debt. Journal of Finance 47: 1367-1400.

28. Thadden E (2004) Asymmetric information, bank lending and implicit contracts: The winner's curse. Finance Research Letters 1: 11-23.

29. Degryse H, Cayseele P (2000) Relationship lending within a bank-based system: Evidence from european small business data. Journal of Financial Intermediation 9: 90-109.

30. Cardone C, Casasola MJ, Samartín M (2005) Do banking relationships improves credit conditions for Spanish SME. Working paper Business Economics Series 6: 5-28.

31. Bhattacharya S, Chiesa G (1995) Proprietary Information, Financia Intermediation, and Research Incentives. Journal of Financial Intermediation 4: 328-357.

32. Chatterjee S, Chavent M, Ding Y, Fu L, Stolowy H, et al. (2006) Disclosure and determinants studies: An extension using the divisive clustering method (DIV). European Accounting Review 15: 181-218.

33. Degryse H, Ongena S (2005) Distance, Lending Relationships and Competition. The Journal of Finance.

34. Angelini P, Salvo D, Ferri G (1998) Availability and cost of credit for small businesses: Customer relationships and credit cooperatives. Journal of Banking and Finance 22: 925-954. 